\title{
Pemersatu Lamongan: Analisis Identitas Kultural Supporter Sepakbola Persela
}

\author{
Ahmad Nidhomuddin ${ }^{1}$, Nikmah Suryandari ${ }^{*}$
}

${ }^{1}$ Universitas Trunojoyo Madura, Indonesia

\author{
A R T I C L E I N F 0 \\ Article history: \\ Received 08 August 2021 \\ Accepted 03 November \\ 2021 \\ Available online 01 \\ December 2021 \\ Kata Kunci: \\ Identitas Kultural; Persela; \\ LA Mania; Curva Boys 1967 \\ Keywords: \\ Cultural Identity; Persela; \\ LA Mania; Curva Boys 1967
}

\begin{abstract}
A B S T R A K
Penelitian ini bertujuan untuk mengetahui identitas kultural suporter sepak bola, khususnya identitas kultural suporter Persela Lamongan yang tergabung dalam Suporter LA Mania dan Curva Boys 1967. Penelitian juga mengkaji bagaimana Persela berhasil menjadi salah satu identitas masyarakat Lamongan. Penelitian ini dianggap penting karena menggunakan supporter sepakbola di Indonesia sebagai objek penelitian, dengan fokus kajian pada identitas kultural yang menjadi salah satu bidang kajian komunikasi. Penelitian ini menggunakan metode deskriptif dengan metode pengumpulan data melalui observasi, wawancara serta dokumentasi. Informan dipilih menggunakan metode purpose sampling. Analisa data dilakukan dengan menggunakan teknik model interaktif Miles dan Huberman melalui proses pengumpulan data, data reduksi, display dan kesimpulan. Hasil penelitian menunjukkan bahwa Persela mampu menumbuhkan rasa percaya diri masyarakat Lamongan akan identitas asalnya. Hal ini dapat dilihat dari antusiasme masyarakat Lamongan kepada Persela baik yang berdomisili di Lamongan maupun yang berada ditanah rantau. Pada perkembanganya hal ini mampu melahirkan identitas kelompok suporter LA Mania dan Curva Boys 1967 yang berbeda
\end{abstract}

\section{A B S T R A C T}

This study aims to determine the cultural identity of football supporters, especially the cultural identity of Persela Lamongan supporters, who are members of LA Mania and Curva Boys 1967 supporters. The study also examines how Persela has succeeded in becoming one of the identities of the Lamongan community. This research is considered necessary because it uses football supporters in Indonesia as the object of research, focusing on the study of cultural identity, one of the areas of communication studies. This research uses a descriptive method with data collection methods through observation, interviews, and documentation. Informants were selected using the purposive sampling method. Data analysis was performed using the interactive model technique of Miles and Huberman through the process of data collection, data reduction, display, and conclusions. The results showed that Persela was able to grow the Lamongan community's selfconfidence in its original identity. This can be seen from the enthusiasm of the Lamongan people for Persela, both those who live in Lamongan and those in overseas lands. In its development, this gave birth to a different identity for the LA Mania and Curva Boys 1967 supporters group. 


\section{Pendahuluan}

Sepak bola adalah salah satu cabang olahraga yang sangat populer dan banyak digemari di dunia. Situs most-popular.net (most-popular.net, 2006) menuliskan hasil survei yang dilakukan oleh Fédération Internationale de Football Association (FIFA) pada tahun 2001 menyatakan bahwa sepakbola adalah olahraga paling populer dimainkan hari ini. Survei ini menunjukkan bahwa lebih dari 240 juta orang memainkan olahraga sepakbola di lebih dari 200 negara di hampir setiap bagian dari dunia.

Dalam studinya tentang konsumsi olahraga, Crawford menunjukkan bahwa penelitian tentang supporter olahraga berfokus hampir secara eksklusif pada mereka yang rutin menghadiri acara olahraga "langsung", sebagian besar mengabaikan bagaimana olahraga dialami dan dikonsumsi dalam kehidupan sehari-hari orang yang jauh dari tempat secara "live"(Stone, 2007). Budaya sepak bola tidak pernah menjadi urusan statis. Mode dukungan struktural dan organisasi informal akan terus menerus mengalami perubahan sesuai dengan pengaruh sosio-historis lainnya (Critcher, n.d.).

Giulianotti mencoba memetakan identitas berbagai jenis suporter sepakbola berdasarkan perubahan yang diamati pada konsumsi sepak bola (Giulianotti, 2002b). Giulianotti memperbarui karya Taylor dan Critcher dengan memberikan taksonomi empat jenis penonton ideal: pendukung,pengikut, penggemar dan flaneur (Taylor, 1971). Definisi ini didasarkan pada motivasi untuk menonton sepak bola dan hubungan spasial dengan lingkungan materi olahraga. Tipologi ini digambarkan Giulianotti dengan gambar berikut (Giulianotti, 2002a)

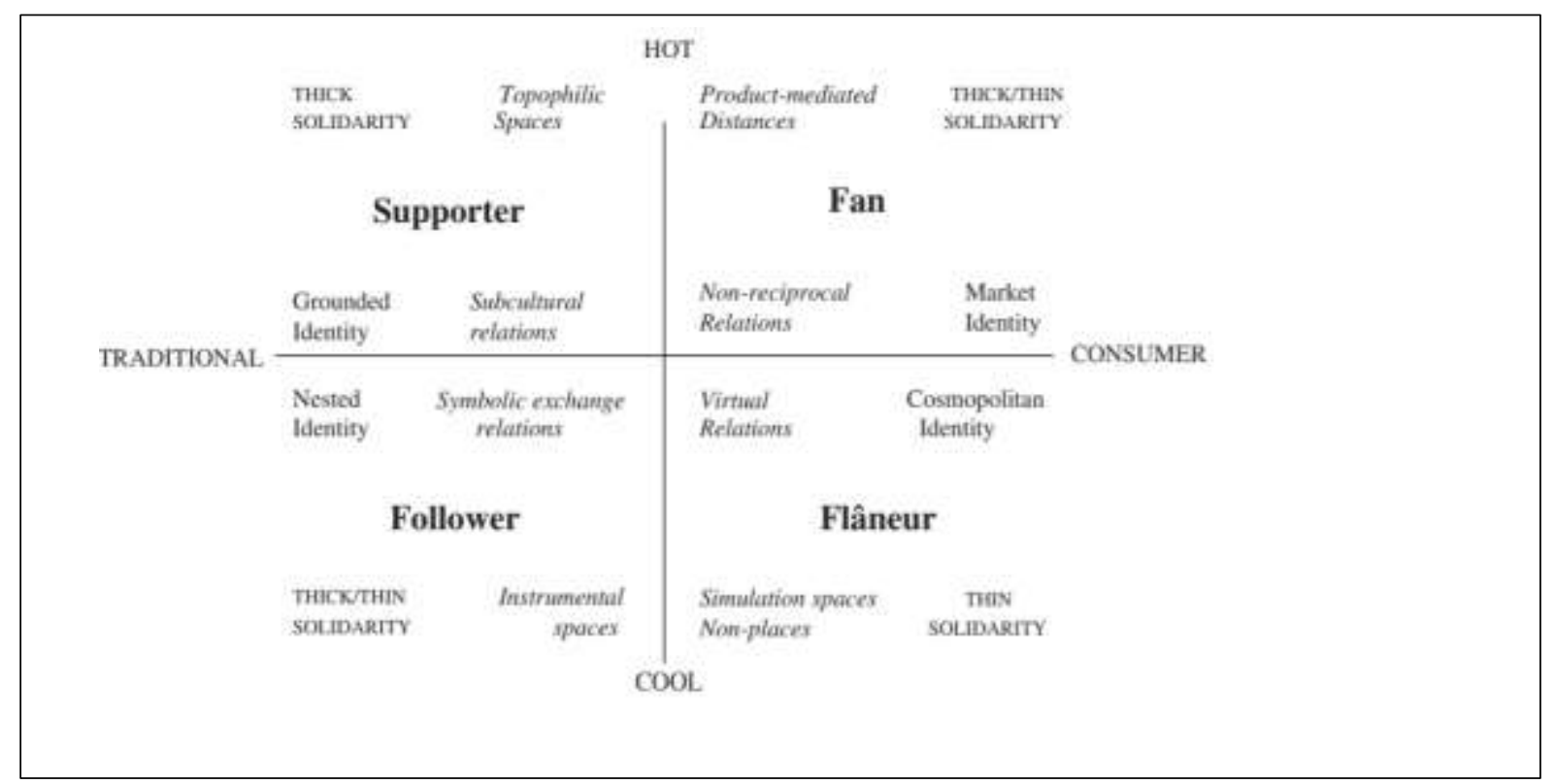

Gambar 1. Tipologi pendukung sepakbola

Sumber: Giulianotti (2002a)

Ada empat kategori penonton yang didukung oleh dua oposisi biner dasar: hot-cool dan traditional-consumer. Jadi, ada empat kuadran dimana penonton dapat diklasifikasikan: traditional/ hot, traditional/cool, consumer/hot, consumer/cool. Empat kuadran mewakili kategori tipe ideal, yang melaluinya kita dapat memetakan perubahan historis dan perbedaan budaya yang dialami oleh penonton tertentu dalam komunitas dan hubungan mereka dengan klub(Giulianotti, 2002a).

Sumbu horizontal tradisional/konsumen mengukur dasar dari investasi individu di klub tertentu: Penonton tradisional akan memiliki identifikasi budaya yang lebih lama, lebih lokal, dan populer dengan klub, sedangkan penggemar konsumen akan memiliki hubungan yang lebih berpusat pada pasar dengan klub sebagaimana tercermin dalam sentralitas mengonsumsi produk klub. Oposisi penonton konsumen tradisional jelas berhutang budi pada kategori penonton awal 
yang dibuat oleh Taylor dan Critcher pada tahun 1970-an, dan setidaknya selama dekade terakhir, istilah-istilah itu telah menjadi pusat perdebatan kritis yang telah mengepung sepak bola dalam domain publik yang lebih luas. Sumbu vertikal panas-dingin mencerminkan derajat yang berbeda, dimana klub adalah pusat proyek pembentukan diri individu. Bentuk loyalitas yang panas menekankan jenis identifikasi dan solidaritas yang kuat dengan klub. Oposisi panas-dingin ini berhutang budi kepada setidaknya dua sumber. Pertama, ahli teori media massa, seperti Marshall McLuhan (McLuhan, 1964) dan Jean Baudrillard (Baudrillard, 1990), menggunakan oposisi ini untuk menjelaskan relasi sosial yang bagus untuk menyusun proses komunikatif yang melibatkan media elektronik. Kedua, perbedaan hot-cool juga diturunkan dari esai Bryan Turner(Turner, 1999) tentang perubahan sejarah dan makna budaya tanda tubuh.

Kegemaran akan sepakbola juga terjadi di Indonesia. Antusiasme masyarakat mulai anak kecil hingga orang tua, dari kota besar hingga pelosok desa, hampir semua menggemari sepak bola. Sepak bola merupakan olahraga yang mempunyai banyak suporter. Suporter adalah penonton yang berpihak pada tim tertentu. suporter sendiri dapat didefinisikan sebagai induvidu atau kelompok yang memberi dukungan dalam suatu pertandingan sepak bola. Soemanto (Handoko, 2008) mengklasifikasikan penonton sepak bola menjadi dua golongan. Pertama, penonton yang murni ingin menikmati permainan cantik saja, tidak peduli dari tim mana pun. Kedua, penonton yang berpihak pada tim tertentu yang sering dikenal dengan istilah supporters. Golongan yang kedua tersebut yang sebagian besar yang lebih emosional dalam mendukung tim kesayangannya untuk menang. Dukungan suporter untuk datang langsung ke stadion dalam pertandingan sepak bola di Indonesia adalah fenomena sosial yang menarik.

Fanatisme penonton sepak bola di Indonesia sebenarnya sudah ada sejak era perserikatan, sebuah kompetisi sepak bola yang mempertemukan kesebelasankesebelasan dari perserikatan sepak bola daerah. Saat era perserikatan, para penonton yang hadir secara langsung ke stadion pada umumnya belum meneganl atribut Tim kesebelasaanya, seperti baju, syal, spanduk dan sebagainya. Tidak ada yel-yel yang di nyanyikan secara bersamaan seperti era sepak bola Indonesia saat ini.

Kecintaan terhadap sebuah klub sepak bola yang sama dan interaksi yang intens di antara pendukungnya, akan melahirkan sebuah kelompok pendukung klub sepak bola. Beberapa kelompok suporter yang terkenal di Indonesia antara lain suporter Persebaya Surabaya yang lebih dikenal dengan sebutan Bonek (Bondo Nekat), Aremania (Arek Malang Mania) sebutan untuk suporter Arema Malang, The Jak Mania (Jakarta Mania) suporter dari klub Ibu kota Persija Jakarta, Viking Persib sebutan untuk suporter asal kota Bandung dan masih banyak yang lainya. selain mempunyai julukan, masing-masing suporter tersebut bisa dibedakan melalui warna atribut yang dikenakan. Seperti contoh suporter Arema dan Persib identik dengan warna biru, suporter Persebaya dan psms identik dengan warna Hijau, The Jak Mania identik dengan warna klub Persija yaitu warna Orange dan sebagainya. Suporter adalah kelompok massa yang dipersatukan karena tujuan yang sama yaitu mendukung tim kebangaanya, selain itu biasanya mereka memiliki keterikatan wilayah yang sama baik itu wilayah dilahirkan ataupun wilayah domisili yang sama. di Indonesia sendiri suporter sepakbola memiliki jumlah yang sangat banyak, hampir disetiap daerah memiliki suporter sepakbola. Hal ini menunjukan bahwa suporter sepakbola bukan hanya sebagai pendukung sebuah klub, tetapi sebagai identitas kewilayahan. Seperti Persebaya sebagai representasi identitas masyarakat Surabaya, setiap orang yang berasal dari Surabaya maka akan dianggap sebagai Bonek. Di Malang, supporter Arema menjadi identitas kota tersebut., begitu juga di daerah-daerah lainya.

Sepak bola sebagai identitas kewilayahan akan menimbulkan persaingan dan gengsi antar masing-masing kelompok suporter, mereka menggangap bahwa wilayahnya lebih baik dari wilayah kelompok lainya, kita bisa lihat rivalitas yang terjadi di indonesia antara suporter Arema malang dengan Persebaya Surabaya antara suporter Persib Bandung dengan Persija Jakarta, suporter PSIM Jogjakarta dengan PSS Sleman dan masih banyak lagi rivalitas yang terjadi. Ratarata kelompok suporter yang berseteru memiliki letak wilayah geografis yang berdekatan. hampir setiap kali kedua belah pihak suporter yang mempunyai rivalitas bertemu akan terjadi intimindasi, kekerasan, tawuran hingga korban jiwa. 
Sepak bola sebagai identitas kewilayahan akan menimbulkan persaingan dan gengsi antar masing-masing kelompok suporter, mereka menggangap bahwa wilayahnya lebih baik dari wilayah kelompok lainya, kita bisa lihat rivalitas yang terjadi di indonesia antara suporter Arema malang dengan Persebaya Surabaya antara suporter Persib Bandung dengan Persija Jakarta, suporter PSIM Jogjakarta dengan PSS Sleman dan masih banyak lagi rivalitas yang terjadi. Ratarata kelompok suporter yang berseteru memiliki letak wilayah geografis yang berdekatan.

Ideologi suporter bukan hanya tentang sepak bola, bukan hanya identitas kewilayahan yang di dukung namun masih banyak alasan lainya bisa juga karena alasan ekonomi, sosial budaya dan politik. Di Skotlandia, suporter menjadikan sepak bola sebagai identitas dua kekuatan agama terbesar yaitu agama Protestan dan Katolik di negara tersebut. Glasgow Rangers adalah representasi dari agama Protestan dan Glasgow Celtics menjadi representasi dari agama Katolik. Di dalam stadion kedua suporter tidak ragu untuk menyanyikan chant bernada intoleran dan sektarian. Di ibu kota Italia tepatnya kota Roma Sepak bola di jadikan sebagai representasi suporter dari dua kelas ekonomi yang berbeda. Suporter AS Roma adalah representasi yang diidentikan dengan kelas menegah bawah, sedangkan suporter SS Lazio identik dengan kelas menengah atas. Di kota Milan sepak bola menjadi representasi Budaya, pendukung klub AC Milan diidentikkan dengan pekerja dan ke hendak dinamis, sedangkan pendukung dari klub Inter Milan adalah Representasi dari kemapanan dan aristokrasi.

Sepak bola Indonesia pada tahun 1998 setelah era Reformasi wajah dan identitas yang melekat didalam kesebelasan-kesebelasan berubah. salah satu klub perserikatan yang mengalami perubahan setelah reformasi orde baru adalah Persela Lamongan, klub perserikatan yang awalnya tidak banyak di kenal di kancah sepak bola nasional kini menjadi di kenal hampir semua masyarakat di Indonesia dan bahkan menjadi identitas dari kota Lamongan itu sendiri.

Penelitian mengenai supporter sepakbola sudah dilakukan, dari beragam perspektif. Seperti penelitian yang dilakukan oleh Meydian Effendy, Endang Sri Indrawati (Effendy \& Indrawati, 2018) berjudul Perilaku Agresif Pada Suporter Sepakbola Panser Biru Banyumanik Semarang. Dalam penelitian ini ditemukan bahwa ada hubungan negatif signifikan antara empati dengan perilaku agresif. Semakin tinggi empati maka semakin rendah perilaku agresif, demikian pula sebaliknya semakin rendah empati maka semakin tinggi pula perilaku agresif pada suporter Panser Biru Banyumanik Semarang. Penelitian mengenai supporter juga dilakukan oleh (Lucky \& Setyowati, 2013) tentang Perilaku Fanatisme Suporter Sepak Bola Novie Lucky. A dan Rr. Nanik Setyowati. Hasil penelitian ini menunjukkan bahwa Bonek dapat dikategorikan sebagai kerumunan (crowd) yang berkumpul pada satu tempat dengan tujuan sama mendukung Persebaya tanpa memandang status, ras, usia, gender, dan agama sehingga terjadi interaksi atas satu sama lain. Sebagai suporter Persebaya, Bonek memiliki pandangan yang sama dalam mendukung Persebaya sehingga lahirnya perilaku fanatisme Bonek.

Dengan melihat penelitian sebelumnya, maka diketahui bahwa penelitian tentang identitas kultural supporter sepakbola di Indonesia belum pernah dilakukan. Tujuan penelitian ini adalah untuk mengetahui dan melakukan analisa terhadap fakta tentang Persela sebagai pemersatu masyarakat Lamongan dan serta iidentitas kultural supporter sepakbola Persela. Melalui penelitian ini diharapkan mampu memberi gambaran mengenai identitas kultural penonton sepakbola khususnya supporter Persela Lamongan.

Identitas kultural adalah rincian karakteristik atau ciri-ciri sebuah kebudayaan yang dimiliki oleh sekelompok orang yang kita ketahui batas-batasanya tatkala dibandingkan dengan karakteristik atau ciri-ciri kebudayaan orang lain (Suryandari, 2017). Menurut Stella TingToomey (Ting-Toomey \& Chung, 2012) identitas kultural adalah identitas yang dihasilkan dari interaksi sosial dibentuk saat kita menyatakan dan berafiliasi dengan kelompok budaya tertentu. Konsep identitas sangat erat kaitanya dengan gagasan budaya. Identitas dapat dibentuk melalui budaya atau sub-budaya tempat seseorang menjadi bagian atau berpartisipasi. Harus diakui bahwa terdapat juga perbedaan teori mengenai identitas yang melihat hubungan antara identitas dan budaya dengan cara yang berbeda pula.

Teori yang dipengaruhi oleh teori-teori modern tentang budaya atau dan identitas cenderung melihat identitas terlahir dalam cara yang cukup langsung akibat keterlibatan dalam 
budaya atau sub-budaya tertentu. Identitas budaya dikaitkan pada beberapa rasa keterkaitan pada kelompok kebudayaan yang lebih besar seperti golongan keagamaan, wilayah suatu daerah, organisasi, kelompok. Seseorang juga bisa memiliki hubungan kebudayaan terhadap masyarakat hetrogen yang lebih besar, yang terdiri dari banyak kelompok kebudayaan yang lebih kecil. Hubungan kebudayaan yang penting bagi banyak orang adalah ke-etnikan.

Identitas etnik terdiri dari gabungan keturunan atau sejarah kelompok dari satu generasi ke generasi lainya. termasuk di dalamanya, negara asal, daerah asal, ras, agama, dan bahasa. Identitas budaya sangat penting dalam menentukan siapa diri kita sebenarnya. Identitas budaya ditandai oleh nilai isi (value content) dan ciri khas (salience). Nilai isi terdiri dari macam-macam evaluasi yang kita buat berdasarkan kepercayaan-kepercayaan budaya. Seperti beberapa kebudayaan mempengaruhi anggotanya agar menilai kelompok atau komunitas di atas induvidu, sedangkan beberapa menekankan pada nilai induvidualistik. Ciri khas merupakan kekuatan afiliasi yang kita rasakan. Kita memiliki ikatan kebudayaan yang sangat kuat atau mungkin terasa agak lemah bagi kita. Bagian identitas kita ditentukan oleh seberapa kuat kita terikat kepada kelompok yang lebih besar dan kejelasan nilai yang muncul dari hubungan ini. Identitas budaya dapat terbentuk struktur kebudayaan suatu masyarakat. Struktur budaya adalah pola-pola persepsi, berpikir, dan perasaan. Identitas budaya dapat diartikan sebagai cerminan kesamaan sejarah yang membentuk sekelompok orang menjadi satu walaupun dari luar mereka tampak berbeda. Hal ini berarti kesamaan sejarah menyatukan mereka. Oleh karenanya identitas budaya yang menjadi hasil karya suatau daerah tersebut. Identitas budaya difungsikan untuk memperkenalkan suatau daerah. seperti saat kita berinteraksi didalam dan diantara kelompokkelompok kebudayaan. Saat kita berinteraksi dengan kelompok yang sama, kita akan merasakan persamaan, kejelasan, keterikatan, dan konsistensi. Tapi ketika kita berinteraksi dengan budaya yang berbeda,

Interaksionisme simbolik adalah proses sosial dalam kehidupan pada kelompok sosial yang menciptakan aturan-aturan. Teori yang dicetuskan George Herbert Mead dan Herbert Blumer ini sangat mengagumi kemampuan manusia untuk menggunakan simbol. Blumer menekankan bahwa studi tentang manusia tidak akan sama dengan studi lainya. sedangkan Mead melihat orang sebagai sesuatu yang kreatif, inovatif, dan bebas dalam menjelaskan pada tiap situasi yang tidak dapat diprediksi. (Littlejohn, Stephan W, 2014). Dalam penelitian ini menggunakan teori Interaksionisme Simbolik karena Perspektif teori ini memandang bahwa individu bersifat aktif, reflektif dan kreatif, menafsirkan dan menampilkan perilaku dihadapan masyarakat (Alamsyah \& Prasetyo, 2019).

Interaksionisme simbolis berdasarkan pada tiga premis. Premis Pertama, prilaku manusia selalu mengarah pada makna yang mereka miliki atau manusia (human being) bertindak terhadap sesuatu berdasarkan makna. Sesuatu (thing) yang dimaksudkan adalah objek fisik seperti pohon atau kursi, makhluk hidup sebagai teman berinteraksi, dan obyek yang sifatnya abstrak seperti keadilan, kebenaran, identitas, kepercayaan, dan lain sebagainya. Premis kedua adalah makna yang ada datangnya dari suatu proses interaksi sosial. makna dalam interaksi simbolik tidak menyatakan sebagai hal yang melekat pada suatu obyek, bukan juga sebagai sebuah proses psikologi, melainkan makna dilihat sebagai hasil dan kreasi yang dibentuk didalam dan melalui aktivitas orang-orang yang ada dalam suatu proses interaksi. Jadi, makna tidak pernah absolut karena makna dicapai berdasarkan suatu proses negosiasi dalam suatu interaksi. Sedangkan premis ketiga mengatakan bahwa makna itu sendiri dikelola dan dimodifikasi melalui proses interprestasi yang digunakan dalam menghadapi obyek sosial untuk bertindak dalam suatu proses interaksi.

Perspektif Interaksionisme Simbolik ini berusaha memahami perilaku manusia dari sudut pandang subjek. Perspektif ini menyarankan bahwa perilaku manusia harus dilihat sebagai proses yang memungkinkan manusia membentuk dan mengatur perilaku mereka dengan mempertimbangkan ekspetasi orang lain yang menjadi mitra interaksi mereka. (Mulyana, 2009). 


\section{Metode}

Pendekatan dalam penelitian ini adalah kualitatif dengan metode konstruktivis. Penelitian ini menggunakan pendekatan konstruktivis karena peneliti berusaha terlibat dengan subjek yang sedang diteliti (Cresswell, 2009). Proses penelitian kualitatif bersifat induktif dimana didalamnya peneliti menciptakan makna dari data-data yang dikumpulkan di lapangan. Penelitian deskriptif bertujuan untuk mendeskripsikan fenomena-fenomena yang ada, baik fenomena alamiah ataupun fenomena buatan manusia. Fenomena itu bisa berbentuk aktivitas, karakteristik, perubahan, hubungan, kesamaan, dan perbedaan antara fenomena yang satu dengan fenomena lainya.

Sumber data primer dalam penelitian ini ialah hasil wawancara dengan pengamat dan anggota dari masing-masing kelompok suporter LA Mania dan Curva Boys 1967. Sumber data sekunder dalam penelitian ini berasal dari buku, sumber internet, dan dokumen tentang kelompok LA Mania dan Curva Boys 1967. Teknik pengumpulan data melalui observasi partisipan, wawancara mendalam, dan dokumentasi. Proses analisis data kualitatif bertujuan untuk memberikan makna pada situasi bukan mencari kebenaran yang difokuskan pada penelitian kuantitatif . Untuk menganalisa data yang telah diperoleh melalui observasi, interview dan dokumentasi, maka penulis menggunakan teknik analisa deskriptif kualitatif dengan pertimbangan bahwa penelitian ini berusaha menggambarkan dan mempresentasikan data secara sistematis, ringkas dan sederhana tentang identitas kultural supporter sepakbola Persela Lamongan.

\section{Hasil dan Pembahasan}

Gray menyatakan bahwa, "kebanyakan orang adalah penggemar sesuatu (Gray et al., 2017). Saat ini, penggemar atau fans telah menjadi fenomena yang sangat berpengaruh dan global(Black, 2021; Booth \& Kelly, 2013). Penggemar sering mendapatkan kekuatan semangat dari kemampuan mereka untuk mengidentifikasi diri mereka sebagai bagian dari kelompok penggemar lain yang didalamnya mereka berbagi kesenangan bersama dan bahkan menghadapi permasalahan yang sama.Penggemar sering diperlakukan dengan dua cara, yaitu ditertawakan atau dipatologikan(Storey, 2014). Penggemar dicirikan dengan citra penyimpangan dan kefanatikan karena dilihat dari perilaku yang berlebihan. Inilah yang disebut dengan stereotip negatif bagi penggemar. Penggemar akhirnya bersatu dan membentuk komunitas sebagai sarana mempertahankan diri dari stereotip negatif tersebut. Banyak literature yang mencirikan bahwa penggemar sebagai suatu penyimpangan dan kefanatikan yang potensial. Kelompok penggemar dilihat sering memiliki perilaku yang berlebihan bahkan mendekati kegilaan terhadap sesuatu hal yang digemarinya tersebut (Storey, 2014)

\section{Persela sebagai simbol pemersatu Lamongan}

Pentingya identitas untuk menumbuhkan semangat kedaerahan. Hal ini disadari oleh M. Masfuk selaku Bupati Lamongan kala itu dengan membangkitkan kembali Persela yang mati suri adalah upaya yang sangat efektif untuk membangun hagemoni masyarakat Lamongan baik yang berdomisili Lamongan maupun di tanah rantau. Hal ini karena Lamongan sering kali keberadaanya di pandang sebelah mata. Untuk mewujudkan bahwa Lamongan bisa sejajar dengan daerah-daerah besar lainya. Pemerintah daerah Lamongan memilih Persela sebagai jalan utama mewujudkan itu dan memilih sepak bola karena sepak bola mampu memobilisasi banyak orang untuk datang ke stadion dan menumbuhkan sikap fanatisme.

"Saya pernah ngobrol dengan pak Masfuk, kenapa pak Persela anda anggarkan dana APBD sebesar ini?, anggaran APBD buat Persela waktu itu di angka 7-12 Milyar. Pak masfuk menjawab, Mif siapa si yang mengenal Lamongan?, tidak ada yang mengenal Lamongan. Kita Mau iklan di media?, tidak mungkin. Iklan di Kompas atau Jawa Pos untuk satu halaman hampir 500 juta hingga 1 milyar. Itu paling hanya bertahan beberapa hari. Iklan di TV?, malah tidak mungkin. Berapa milyar yang harus kita bayarkan untuk iklan di TV? Tentu iklan yang dikeluarkan untuk iklan di media massa bisa jauh 
lebih besar dari pada anggaran persela untuk satu musim kompetisi. Maka persela sebagai media untuk mengenalkan Lamongan ke publik". (Fahamsyah, 2019b)

Persela adalah media yang paling efektif dalam mengenalkan Lamongan ke seluruh penjuru Indonesia. Perlahan tapi pasti kesebelasan Persela mulai naik kasta ke liga tertinggi sepak bola tanah air ini. Masyarakat Lamongan yang berada di tanah rantau khususnya pedagang makanan, mulai membangkitkan semangat kedaerahaanya. Dulu sebelum eksistensi Persela di persepakbolaan nasional, masyarakat Lamongan yang memilih untuk menyebutkan Surabaya sebagai pilihan identitasnya, Saat ini Ketika mereka baik yang muda maupun yang tua mendapatkan pertanyaan asal daerahnya. Bisa di pastikan mereka memilih menyebutkan Lamongan sebagai identitasnya.

\section{Spanduk Pecel Lele Menjadi Identitas Suporter Persela}

Semenjak Persela bermain di Liga tertinggi Indonesia, Persela mampu membangkitkan rasa percaya diri masyarakat Lamongan akan identitas asal mereka. Rasa percaya diri itu tidak hanya ada pada jiwa masyarakat yang berdomisili di Lamongan. Tapi juga merasuk ke jiwa seluruh masyarakat Lamongan di perantauan. rasa percaya diri akan identitas asalnya tergambar dari cara mereka yang tidak segan mencantumkan nama Lamongan di tempat mereka berjualan Ketika Persela bertanding di luar pulau, disetiap pelosok negeri ini selalu ada suporter Persela yang mendukung secara langsung ke stadion. Mereka adalah masyarakat Lamongan yang berada di perantauan. Bahkan menjadikan sebuah tradisi dan budaya bagi suporter Persela yang ada di tanah rantau untuk bisa melakukan penyambutan dari bandara dan jamuan makan bersama antar suporter dan kesebelasan Persela saat bertandang ke daerah perantauan mereka. Mulai dari anakanak baik yang muda maupun yang tua, perempuan atau laki-laki membaur jadi satu untuk melakukan penjamuan. Sebuah tradisi yang hanya ditemui dan dilakukan oleh suporter Persela.

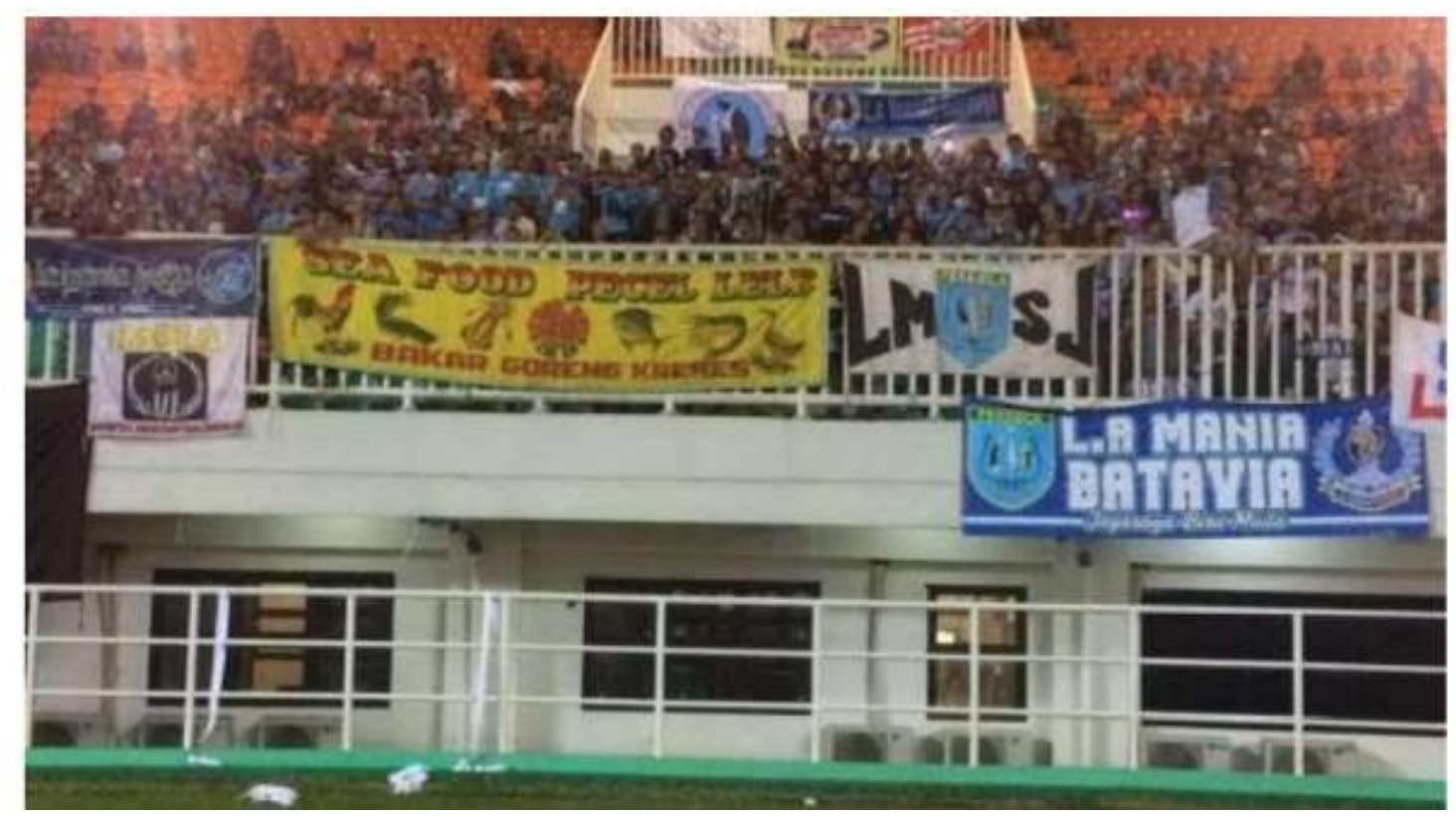

Gambar 2. Spanduk Pecel Lele Saat Pertandingan Persela

Sumber: Tribunnews.com

Gambaran sebuah rasa percaya diri akan identitas asalnya tercermin dengan melihat bagaimana mereka melafalkan nama Lamongan di tempat laga pertandingan Persela. Para supporter Persela di daerah rantau, tidak sungkan untuk membawa spanduk tempat makan mereka ke dalam stadion untuk mendukung Persela. Spanduk itu biasanya dibentangkan dipagar tribun stadion bersama spanduk-spanduk suporter saat persela melakoni laga pertandingan terlebih saat melakoni laga tandang. 
"Benar mas, saya sudah pernah beberapa kali melakukan tour ke kota-kota lain, ke luar Jawa juga sudah pernah. Waktu di Samarinda, Tenggarong dan Banjarmasin, Hampir Disetiap pertandingan Persela selalu ada orang-orang Lamongan yang membawa spanduk pecel lele warung makan mereka ke dalam stadion".(Septya Nugraha, 2019)

Penggunaan simbol oleh suporter Persela ini mirip mirip dengan hampir semua suporter tim sepakbola dimanapun. Hal yang sama juga ditujukkan oleh siporter Persija. The Jakmania menggunakan simbolsimbol verbal dan nonverbal ketika berinteraksi satu sama lain. Simbolsimbol yang digunakan antara lain: warna orange yang menghiasi benda-benda yang digunakan dalam kehidupan sehari-hari (tas, gelang, stiker, baju, topi dan sebagainya), jari telunjuk dan jempol yang melambangkan huruf J (The Jakmania atau Jakarta), mars The Jakmania, lagu-lagu dan sebagainya(Sabarina Sitepu \& Desiana Setyaningsih, 2011).

\section{Joko Tingkir Sebagai Julukan Persela}

Hampir semua kesebelasan sepak bola di Indonesia mempunyai julukan pada masingmasing klubnya. Pada umumnya julukan itu dilekatkan dengan nama hewan, kerajaan, warna kebesaran atau nama tokoh-tokoh tempat asal kesebelasan tersebut. Persatuan sepak bola Lamongan atau lebih dikenal dengan Persela memilih Joko Tingkir sebagai julukan klubnya yang lebih dikenal dengan Laskar Joko Tingkir.

"Inspirasi datang dari almarhum Gus Dur saat menjabat sebagai presiden Indonesia, Gus Dur pernah menyinggung tentang Joko Tingkir saat berpidato di Tugu Pahlawan, Surabaya. Ada petilasan Joko Tngkir di Lamongan. Lokasinya ada di Dukoh, Pringboyo, Maduran, Lamongan. Tempatnya di yakini sebagai makam Joko Tingkir. Setelah Masfuk menelusuri apa yang di ucapakan oleh Gus dur bahwa petilasan Joko Tingkir ada di Lamongan. Ternyata benar adanya. Ada makamnya. Dari dasar keyakinan itu. Masfuk memilih Joko Tingkir sebagai julukan persela karena menurut dia, nama Joko Tingkir memiliki nilai Jual yang tinggi dibandingkan nama lainya dan juga bisa mendongkrak nama Persela"(Fahamsyah, 2019a).

\section{Simbol-simbol verbal LA Mania}

LA Mania adalah salah satu kelompok suporter Persela Lamongan yang terinspirasi untuk menggunakan kata "mania" dibelakang nama kelompoknya. LA Mania sendiri merupakan akronim dari kata Lamongan Asli mania. LA Mania adalah suporter Persela yang sering menggunakan simbol sebagai cara mereka untuk menyampaikan pesan kepada khalayak. Suporter LA Mania mempunyai logo yang menandai bahwa kelompok tersebut adalah kelompok suporter sepak bola yang mendukung kesebelasan Persela Lamongan. Dengan kemunculan Logo Laskar Joko Tingkir yang menjadi ikon dari Persela Lamongan, suporter LA Mania juga merasakan adanya kecocokan dengan logo tersebut. Karena kuatnya ikon gambar orang berambut panjang, Logo ini mudah diterima dan diingat oleh anggota LA Mania. bagaimana gaya rambut panjang sangat populer dan digandrungi para pemuda pada era itu. Gambar sosok Joko Tingkir ini dilukis oleh M Ridwan yang terinspirasi dari sosok pahlawan Lamongan yaitu Kadets Soewoko. Logo Joko Tingkir dipilih atas kesepakatan saat konggres anggota kelompok suporter LA Mania.

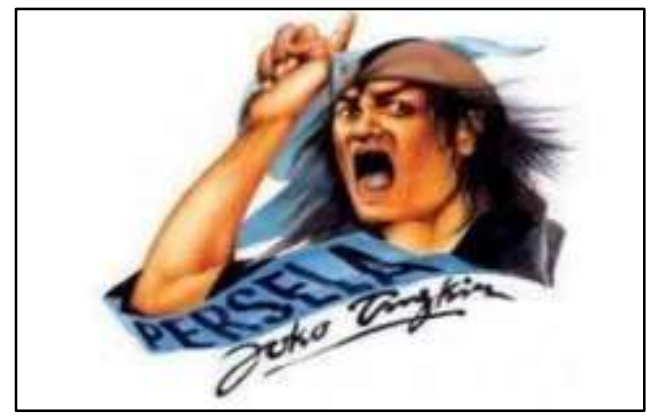

Gambar 3. Logo Joko Tingkir 
Makna dari Logo kelompok LA Mania dengan sosok gambaran Joko Tingkir yang berambut panjang terurai menggenakan blangkon di kepala. Dibawah lengan terdapat kain biru muda bertulisakan Persela dengan huruf besar kemudian dibawahnya lagi ada tulisan Joko Tingkir. ekspresi teriakan yang melambangkan semangat juang yang tinggi, tangan yang mengancungkan satu jari keatas melambangkan harapan besar LA Mania kepada Persela untuk menjadi nomer satu di kancah tertinggi liga Indonesia. Hal ini seperti diungkapkan oleh Saptya berikut:

"Logo 2001 pada waktu itu kita menggadakan lomba logo, bermacam-macam gambar, yang mengadakan Jawa Pos, akhirnya pada waktu itu yang mendekati, karena sosok joko tingkir ini kan masih di angan-angan, sehinga logo Joko Tingkir dengan tangan mengacung satu yang dipilih, kesepakatan dengan teman-tmen dengan tim dari Radar kebetulan yang juara dari desa kami mas duan, kebetulan mereka juga yang membuat logo bonek mania, bonek sendiri terinspirasi dari kepala kadets suoewoko, lomba 1997 kalau gak salah. Sebelum final persebaya lawan PSIS Semarang Persebaya kalah 1-0, LA Mania belum ada, yang membuat logo juara satu ya mas duan itu. Filosofi logo Joko Tingkir mengacungkan angka 70 satu karena masyarakat Lamongan mayoritas santri muslim. Percaya kepada Tuhan Yang Maha Esa, semoga Persela juga juara satu".(Nugraha, 2009).

Dalam perkembanganya LA Mania juga tidak hanya menggunakan logo Joko Tingkir pada atribut mereka. Mereja juga mempunyai logo dengan gambar tangan membentuk huruf "L" kemudian disambung dengan huruf " $A$ ". Logo tangan berbentuk LA ini kemudian menjadi identitas logo kelompok suporter mereka. Logo gambar tangan ini juga banyak digunakan pada atribut baik kaos, syal, giant flag, Kartu Tanda Anggota , maupun spanduk-spanduk mereka.

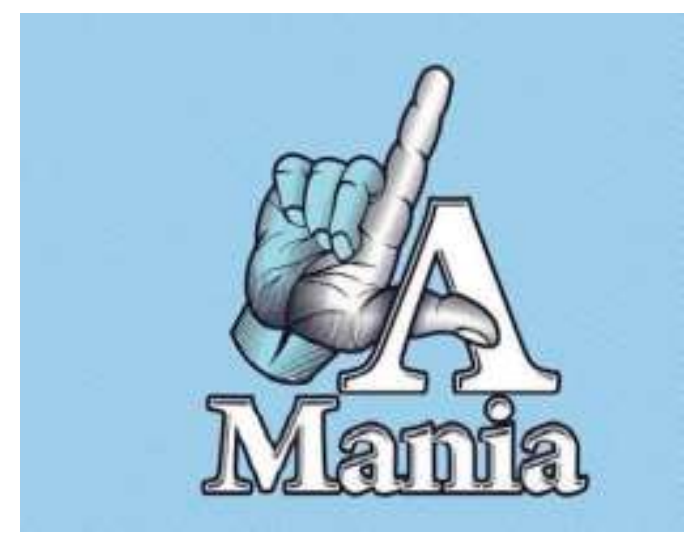

Gambar 4. Logo LA Mania

"Bergerak dan Bersatu” Sebagai Jargon LA Mania

LA Mania memiliki jargon "Bergerak Dan Bersatu", slogan Bergerak dan bersatu sering dikumandangkan oleh LA Mania pada saat mendukung Persela.

"Moto bergerak dan bersatu tercetus pada tahun 2001, pada waktu itu ada kongress pengurus LA mania yang baru terbentuk. Kita rapat dengan pengurus, bonek sudah punya motto waktu itu, The Jak, Arema. Bergerak dan bersatu bermakna kalau kita tidak bergerak persatuan tidak akan terwujud, mangkanya kita harus bergerak maka persatuan akan terwujud, mengapa terbentuk korwil-korwil di seluruh indonesia. Kalau LA Mania tidak bergerak kan tidak mungkin ada LA Mania Banjarmasin, LA Mania Balikpapan. LA Mania Tenggarong"(Nugraha, 2009)

\section{Chants LA Mania}

Chants adalah salah satu bentuk dukungan kepada tim berupa nyanyiannyanyian yang disuarakan bersama-sama. setiap kelompok suporter mempunyai ciri khas chants-chants masingmasing. Chants adalah salah satu bentuk dukungan yang sangat penting dilakukan oleh suporter 
untuk memberikan suntukan motivasi kepada para pemain yang bertanding diatas lapangan hijau. selain itu, chants adalah bentuk teror kepada tim lawan yang dilakukan oleh suporter lewat nyanyian-nyanyian yang disuarakan bersama. Bagi suporter chants adalah sebuah doa dan harapan. LA Mania sendiri adalah suporter yang menyanyikan chants-chants disetiap laga, namun suara chants itu sudah tidak selantang dulu. Biasanya suara itu hanya bertahan pada 15 menit awal dan saat ada momen gol terdengar.

"Dari dulu lagu LA Mania ya gitu-gitu aja mas tidak pernah berubah. Biasanya kalau nyanyi ya kami anak LA Mania, Kami pendukung Persela. kalau gak gitu ya nang kene aku ngeteni kowe tak rewangi ora nyambut gawe. pokoknya setiap musim ya itu-itu aja”.(Umam, 2009)

\section{Warna Biru Muda Sebagai Identitas LA Mania}

Kelompok LA Mania identik dengan atribut yang dominan menggunakan warna biru muda (biru langit) terutama pada pakaian yang mereka kenakan. Mereka mengunakan atribut berwarna biru muda saat mendukung Persela Lamongan baik laga kandang maupun tandang. sesuai dengan warna kebesaran tim Persela yaitu biru muda. Jika ada warna lain selain warna biru muda, maka itu hanya variasi diantara warna biru muda yang mendominasi. Rata-rata kelompok 74 suporter yang mengikuti kultur Mania biasanya kelompok mereka menggunakan warna atribut sesuai dengan warna jersey tim yang didukungnya.

"Dari dulu awalnya terbentuknya LA Mania Atribut LA Mania berwarna biru muda karena kostum Persela kan berwarna biru muda. Pada saat persela main di kandang atau saat kita melakukan tour ke luar kota, ke stadon tim lain. Mayoritas anggota kelompok suporter LA Mania dominan menggunakan kaos berwarna biru muda dengan tulisan persela ataupun LA Mania, saya kalau nonton ke stadion juga menggunakan kaos La Mania". (Septya Nugraha, 2019)

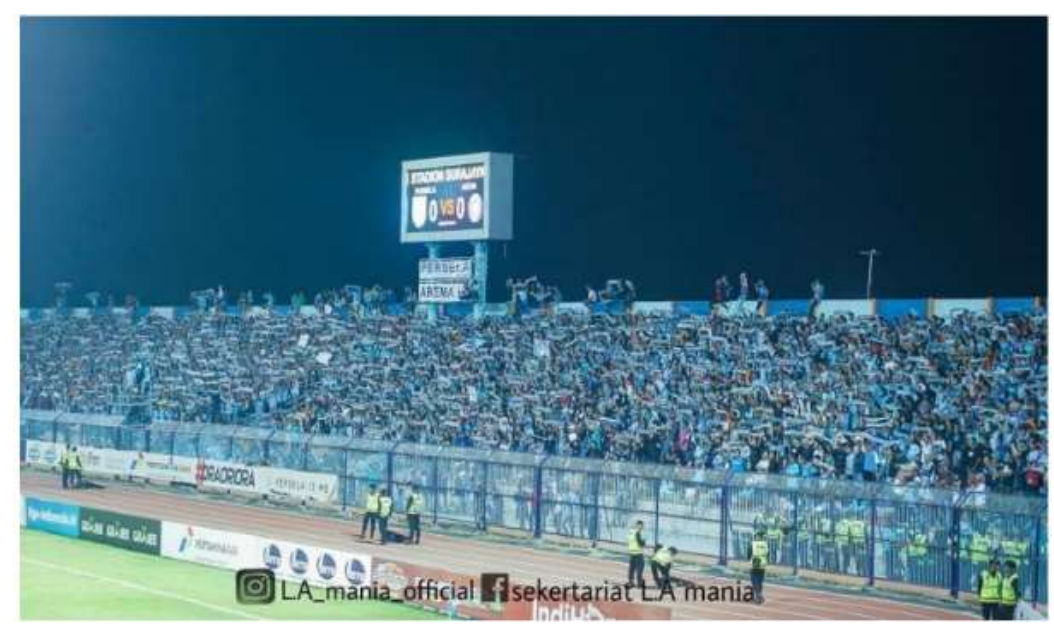

Gambar 5. Dominasi warna biru muda di stadion

Anggota suporter LA Mania menggenakan atribut tidak hanya saat pertandingan mendukung Persela di stadion saja. Tapi tidak jarang mereka juga menggunakan atribut yang identik dengan Persela dan kelompok LA Mania dalam aktifitas keseharianya. Seperti saat kuliah, berpergian ke luar kota, hang-out dengan teman-temanya. Beberapa diantara mereka bahkan sering membeli atribut baru setiap musimya, baik itu jersey, scraf, kaos LA Mania dan aksesoris lainya.

"Kalau saya sering mengenakan kaos Persela atau LA Mania waktu kuliah. Saya kan sering touring pakai motor sama teman-teman, kaos karo syal saya bawa. Tidak boleh ketinggalan. Buat photophoto. Kalau kaso LA Mania saya punya banyak, LA Mania Gresik setiap tahun produksi kaos, saya sudah punya tiga, saya juga punya beberapa syal LA Gresik"(Umam, 2019). 


\section{Curva Boys 1967 : Suporter Persela berkultur Ultras}

Sebelum berdiri sendiri dengan nama Curva Boys 1967, mereka adalah sebuah komunitas bagian dari kelompok LA Mania. Lahirnya kelompok suporter baru dengan kultur ultras. semacam ini adalah fenomena yang jamak ditemui pada kelompok suporter klub sepak bola di Indonesia. Biasanya ditandai dengan adanya kelompok suporter yang memiliki nama berbeda meskipun mendukung tim yang sama. Ultras adalah sebuah ideologi suporter yang berasal dari negara Italia. Mulanya mayoritas anak-anak muda yang berstatus pelajar, mahasiswa, pekerja berganji rendah dan pengganguran ini memiliki uang terbatas. Mereka memilih untuk melihat pertandingan sepak bola di tribun belakang gawang, karena disana harga tiket paling murah. Kata curva digunakan untuk merujuk pada tribun belakang gawang yang berbentuk lengkungan. Mereka benyanyi, memasang spanduk, mengibarkan bendera-bendera yang berukuran raksasa, menyalakan macam-macam jenis kembang api dari bom asap sampai red flare. Curva Boys 1967 menjadi identitas baru kelompok suporter dari Lamongan yang mendukung Persela. Kata Curva bermakna titik lengkung tribun stadion yang menjadi tempat mereka dan kata Boys sendiri menjadi penanda bahwa kumpulan pemuda ini adalah para anak muda yang menepati Tribun Lengkung tersebut. 1967 merupakan tahun berdirinya Persela Lamongan. Dengan menyertakan angka 1967 menjadi bukti bahwa mereka adalah pendukung setia Laskar Joko Tingkir.

"Dulu itu buat nama curva boys, kita mikir biar bisa dipakai saat menempati tribun nord atau sud saat laga tandang. Seandainya kita tour ke Malang terus di tempatkan di tribun selatan tapi kita memakai nama curva nord, kok tempatnya di selatan kan gak etis. Akhirnya pakai nama boys setelah kata curva,kebetulan saat itu anggotanya terdiri dari anak-anak muda tidak ada yang tua"(Suhermawan, 2019).

\section{"No Leader Just Togheter": Identitas Curva Boys 1967}

Kelompok Curva Boys menganut ideologi "no leader just togheter" yang bermakna tidak ada pemimpin semuanya sama. hal ini dimaksudkan agar semua anggotanya memiliki kewajiban dan hak yang sama saat penegambilan keputusan kelompok Curva Boys. Mereka beranggapan bahwa adanya struktural kepengurusan hanya akan membuat sebuah sekat antar anggotanya. mereka lebih memilih untuk menggunakan forum musyawarah. Curva Boys 1967 mayoritas beranggotakan anak muda, gaya mendukung di tribun stadion dengan pertunjukan-pertunjukan yang belum ada di Lamongan sebelumnya, seperti mengibarakan bendera raksasa, hand banner, membuat koreografi kertas berbentuk mozaik-mozaik dan tulisan, menyalakan kemabang api. Gaya dalam mendukung yang berbeda itulah yang membuat Curva Boys 1967 menjadi sorotan setiap kali ada pertandingan di Lamongan, akhirnya banyak anak-anak muda yang tertarik untuk bergabung dengan Curva Boys 1967. Tribun utara Gelora Surajaya Lamongan yang berkapasitas sekitar empat sampai lima ribu 80 orang selalu dipenuhi anggota Curva Boys disetiap kali pertandingan kandang. Saat ini anggota mereka berada diberbagai penjuru Lamongan dan ada juga beberapa yang ada di luar kota Lamongan seperti Curva Boys Surabaya dari kota Surabaya, Curva Boys Capitale dari Jakarta di Jakarta. Curva Boys Mojokotingkir dari Mojokerto. Terbentuknya distrik disetiap daerah untuk memudahkan memobilisai dan mengkordinir anggota Curva Boys yang berada di berbagai wilayah tersebut. Distrik adalah istilah yang digunakan untuk wadah kordinator suatu wilayah tertentu. Saat ini distrik mereka berjumlah 22 . Untuk bisa membuat distrik minimal harus ber-anggotakan 40 orang asli atau berdomisli di daerah tersebut dan konsisten hadir disetiap pertandingan kandang. Biasanya suatu distrik tergabung dari berbagai kecamatan yang berdekatan seperti Curva Boys Kamtiso gabungan dari 3 kecamatan Karangbinangun, Tikung dan Sarirejo. Curva Boys Lamasea terdiri dari kecamatan Laren, Maduran, Sambeng.

"Distrik itu terbentuknya tahun 2013 seingatku, dulu itu masih pakai istilah zona. Jadi ada zona utara, zona tengah, timur, selatan. Terus anggotanya tambah banyak, tahun 2013 diganti dengan distrik. Gunanya ditrik buat kordinasi teman-teman. Hampir setiap kecamatan di Lamongan ada distriknya dan sebagian ada diluar kota. Kayak Curva Boys Surabaya, Curva boys Mojokotingkir dari 
Mojokerto. Curva Boys Capitale dari Jakarta. Kalau mau buat ditrik syratanya anggotanya minimal 40 orang asli daerah tersebut. Kenapa kok harus minimal 40 orang asli dari daerah tersebut, karena kalau tidak dibuat kayak gitu pasti banyak yang membuat distrik baru. Kalau awal semangatnya masih membara, konsisten itu yang sulit"(Hernandes, 2019)

\section{Chants dan Atribut Curva Boys 1967}

Saat mendukung Persela di stadion Surajaya suara mereka lebih lantang dibandingkan kelompok suporter lainya. Chant-chant yang dinyayikan oleh Curva Boys biasanya berbahasa Indonesia, Inggris dan Italia. Chants "persela till i die" merupakan sebuah chants dalam bahasa Inggris. Chants yang berbahasa Italia "Bianco Leste Ale", "Forza Persela Vinci Per Noi" selalu mereka mereka nyanyikan baik saat mendukung di dalam stadion.

"Mungkin sebabnya kita Curva Boys awalnya kan mencari referensi tentang suporter di youtube baik itu suporter yang ber kultur ultras di Indonesia maupun di luar negeri. Jadi sampai sekarang beberapa chants ada yang pakai bahasa Italia sama bahasa Inggris. Kalau chats bianco leste itukan mempunyai arti biru putih dalam bahasa Italia, Persela kan mempunyai warna utama biru muda, jadi chants itu mengambarkan Persela".(Suhermawan, 2019)

Ada yang membedakan Curva Boys 1967 dengan kelompok suporter lain di Lamongan melalui bahasa pada atribut yang mereka kenakan, hampir semua atribut mereka menggunakan bahasa asing seperti seperti kata away days, Persela days, you'r never walk alone, Lamongan till i die, Persela never give up. Atribut juga menggunakan bahasa Italia, seperti Forza Persela vinci Per Noi, Persela per sempre, la nord'e conte, Bianco leste ale.

"Ya karena terisnpirasi dari suporter luar negeri, kan awal kita berdiri di kaos kita tulisanya kan pakai bhasa Inggris, kaos yang depanya bertuliskan No. 1 itu kaos pertama kita, kan itu pakai bahasa Inggris. Kaos yang dipakai waktu pertama kali kita tour ke madiun, laga usiran lawan Persija mergone stadion surajya direnovasi dulu. Terus kaos yang depannya logo curva yang belakangnya bertuliskan forza persela vinci per noi kan itu pakai bahasa Italia. Mungkin gara-gara awal kita muncul dulu, jadi sampai sekarang di ikuti teman-teman"(Hernandes, 2019).

Sedangkan untuk logo, kelompok Curva Boys 1967 berbentuk lingkaran dengan tulisan Curva Boys 1967 diatas, terdapat gambar bola dan gerigi tangan sebagai pemisah tulisan Ultras Persela. ada gambar kepala dengan menggenakan topi dan bercadar berwarna biru muda (warna langit) di tengah lingkaran tersebut.

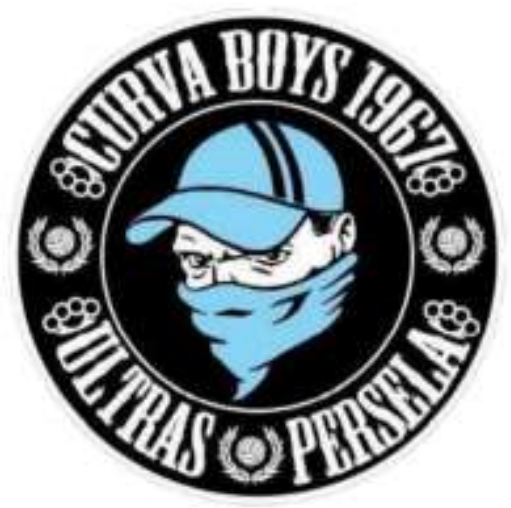

Gambar 6. Logo Curva Boys 1967

"Logo Curva Boys dibuat setelah CB berdiri, anggota masih sedikit banget. Waktu itu kita menempati sektor 9 Surajaya. Dulu waktu pertama kali logo CB samping kiri dan kanan terdapat angka 9 karena kita hanya menempati sektor 9. Terus setelah anggotanya banyak dan menyebar di tribun utara. kita rubah menjadi bola" (Hernandes, 2019). 


\section{"SRIT" Sebagai Jargon Curva Boys 1967}

Jargon Curva Boys 1967 adalah "SRIT" singkatan dari Solidarty, Respect, Intelect, Talent. Jargon SRIT mempunyai tujuan dan makna tersendiri bagi setiap anggotanya, dengan adanya jargon tersebut diharapkan para anggota Curva Boys 1967 mempunyai rasa saling menghormati dan menghargai, harus mempunyai ide-ide yang kreatif untuk Persela Lamongan

"Jadi disini, Curva Boys harus mempunyai sifat solidaritas kepada sesama anggotanya. terus yang mudah harus menghormati yang tua dan yang tua harus menghargai yang muda, intinya saling menghormati. Anggota CB harus berpikir intelek, harus selalu punya ide-ide kreatif" (Hernandes, 2019)

Selain jargon SRIT, warna hitam menjadi Identitas Curva Boys 1967. Kelompok supporter Curva Boys 1967 mewajibkan anggotanya memakai jersey atau kaos hitam. Warna hitam dimaksudkan untuk mengkritik kelompok suporter yang sudah ada di Lamongan. Warna hitam juga sebagai identias yang membedakan Curva Boys 1967 dengan kelompok suporter lain. Warna hitam bagi mereka adalah simbol perlawanan. Pada perkembangnya banyak sekali anggota Curva Boys tidak hanya memakai jersey ataupun kaos yang berwarna hitam saja menutup wajah dengan bandana. Banyak dijumpai anggotanya yang memakai atribut brand dari luar negeri baik kaos, jaket, sepatu yang identik dengan olahraga, seperti Adidas, Nike, Puma, Filla, Lionsdale, Stone Island.

"Sebenarnya ultras itu gak harus berpakaian hitam, kalau Curva Boys itu wajib pakai jersey atau pakaian hitam. Kenpa sekarang kok 91 identik dengan warna hitam, Karena dulu waktu pertamakali berdiri, waktu itukan Curva Boys sebagai kritik sosial sama suporter Lamongan waktu itu. Warna hitam itu simbol perlawanan kita, selain itu buat membedakan anggota Curva Boys karo Suporter lainya. mangkanya pernah posting di media sosial, kalau ultras itu tidak harus hitam sebenernya, lebih baik kalau berjersey"(Suhermawan, 2019).

"Tergantung induvidu, sebenarnya ultras itu ya tidak harus casual. Yang keren harus pakai jersey Persela Lamongan. BrandcCasualkan identik dengan harganya yang mahal, kenapa suporter di Inggris pakai casual tidak memakai jersey. Casual di Inggris itu identik dengan holiganisme, ketika chaos kalau pakai jersey kan dengan mudah teridentifikasi lawan, jadi mudah ketangkap. Mangkanya tujuan berpakaian casual itu untuk mengelabuhi lawan. Biar terlihat orang mapan, pdahal ya pengen chaos"(Suhermawan, 2019).

Curva Boys 1967 juga mempunyai aturan-aturan yang harus ditaati oleh anggotanya diantaranya adalah aturan yang mewajibkan semua anggota Curva Boys 1967 untuk mengenakan sepatu saat mendukung Persela di tribun utara Suarajaya. Bila ditemui saat pertandingan tidak mengenakan sepatu maka akan diperingatakan untuk pindah tribun, karena bagi mereka, stadion adalah tempat yang sakral maka harus mengenakan atribut terbaik untuk datang ke stadion. Hal itu dilakukan sebagai bentuk penghormatan kepada Persela yang sedang bertanding.

"Anggota Curva Boys kalau nonton ke stadion tidak boleh pakai sandal, wajib bersepatu. Kenapa kok bersepatu, biar lebih etis kalau dilihat dari pada memakai sandal. Manfaat lainya saat ngechants, koreografi lompat-lompat kalau terinjak orang lain itu tidak sakit. Selain itu bentuk penghormatan buat pemain di lapangan. Pokoknya stadion itu tempat yang sakral, kenakan pakaian terbaikmu"(Suhermawan, 2019).

\section{Simpulan dan Saran}

Persela mampu membangkitkan rasa percaya diri masyarakat Lamongan dengan identitasnya. Tim berjuluk Laskar Joko Tingkir kini telah menjadi ikon Lamongan. Persela sebagai representasi masyrakat dan kota Lamongan, memiliki kelompok supporter yaitu LA mania dan Curva Boys 1967. Kedua kelompok supporter memiliki identitas kultural yang spesifik. LA Mania identik dengan warna biru muda dengan jargon "Bergerak dan Bersatu". Curva Boys 1967 sendiri 
ada kelompok suporter yang beraliran ultras, atribut-atribut mereka identik dengan warna hitam, dengan jargon SRIT (Solidarty, Respect, Intelect, Talent)

\section{Daftar Rujukan}

Alamsyah, M. I., \& Prasetyo, I. J. (2019). Persebaya dan Bonek: Simbol-Simbol Komunikasi Supporter Sepakbola Komunitas "Syndicate Bonek Keputih (SBK)." Communicatus: Jurnal Ilmu komunikasi, 2(2), 203-216. https://doi.org/10.15575/cjik.v2i2.5032

Baudrillard, J. (1990). Seduction. Macmillan.

Black, R. W. (2021). Adolescents and Online Fan Fiction. Peter Lang Verlag. https://www.peterlang.com/document/1105746

Booth, P., \& Kelly, P. (2013). The changing faces of Doctor Who fandom: New fans, new technologies, old practices. Participations, 10(1), 56-72.

Cresswell, J. W. (2009). Research Design : Qualitative, quantitative, and mixed methods approaches.

Critcher. (n.d.). , 'Football Since the War'; Fishwick, English Football and Society 1910-1950; Holt, Sport and the British; Mason, Association Football and English Society.

Effendy, M., \& Indrawati, E. S. (2018). Hubungan antara empati dengan perilaku agresif pada supporter sepakbola panser biru banyumanik semarang. Jurnal Empati, 7(3), 140-150.

Giulianotti, R. (2002a). Supporters, followers, fans, and. 26(1), 25-46.

Giulianotti, R. (2002b). Supporters, Followers, Fans and Flaneurs. Journal of Sport and Social, 26(1).

Gray, J., Sandvoss, C., \& Harrington, C. L. (Ed.). (2017). Fandom, Second Edition. NYU Press. https://doi.org/10.2307/j.ctt1pwtbq2

Handoko, A. (2008). Sepak Bola Tanpa Batas. Kanisius.

Littlejohn, Stephan W, dan K. A. F. (2014). Theories of Human Communication. Jakarta: Salemba Humanika.

Lucky, N., \& Setyowati, N. (2013). Fenomena Perilaku Fanatisme Suporter Sepak Bola (Studi Kasus Komunitas Suporter Persebaya Bonek Di Surabaya). Kajian Moral dan Kewarganegaraan, 1(1), 180-195.

McLuhan, M. (1964). Understanding media.

Mulyana, D. (2009). Ilmu Komunikasi: Suatu Pengantar. Jawa Barat: Remaja Rosdakarya.

Sabarina Sitepu, Y., \& Desiana Setyaningsih, F. (2011). Konstruksi Identitas Suporter Sepakbola Di Indonesia (Studi kasus pada Kelompok Suporter The Jakmania). Jurnal Ilmu Sosial, Fakultas Isipol-Universitas Medan Area, 4(1), 60-78.

Stone, C. (2007). The Role of Football in Everyday Life. Soccer \& Society, 8(2-3), 169-184. https://doi.org/10.1080/14660970701224319

Storey, J. (2014). But what is Cultural Studies? In Studying British Cultures. Routledge. https://doi.org/10.4324/9781315016030-11

Suryandari, N. (2017). Eksistensi Identitas Kultural. Komunikasi, 11(21).

Taylor, I. (1971). 'Football Mad: A Speculative Sociology of Football Hooliganism.' E. Dunning. London: Frank Cass, 1971. In The Sociology of Sport: A Selection of Readings.

Ting-Toomey, S., \& Chung, L. C. (2012). Understanding Intercultural Communication. Second Edition.

Turner, B. S. (1999). The possibility of primitiveness: Towards a sociology of body marks in cool societies. Body \& Society, 5(2-3), 39. 